\title{
Skin rash: a manifestation of early congenital syphilis
}

\section{Sara Tavares Ferreira, ${ }^{1}$ Cátia Correia, ${ }^{1}$ Monica Marçal, ${ }_{1}^{2}$ Madalena Lopo Tuna ${ }^{2}$}

${ }^{1}$ Pediatrics Department, Centro Hospitalar de Lisboa Ocidental, Lisboa, Portugal

${ }^{2}$ Neonatal Intensive Care Unit, Centro Hospitalar de Lisboa Ocidental, Lisbon, Portugal

\section{Correspondence to} Dr Sara Tavares Ferreira, saraferreira25@gmail.com

Accepted 12 May 2016

\section{CrossMark}

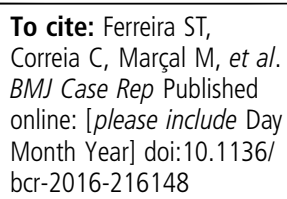

\section{DESCRIPTION}

A 34-week-old gestational baby boy, weighing $2104 \mathrm{~g}$, was born with multiple organ dysfunction and a skin rash. During pregnancy, the mother had a reactive venereal disease research laboratory (VDRL) test $(1: 16)$ that didn't receive any treatment.

After birth, a target erythaematous maculopapular rash on the child's hands and soles (figures 1A, $\mathrm{B}$ and 2) was evident. He also had hepatosplenomegaly, pneumonitis, anaemia (haemoglobin $11.3 \mathrm{~g} / \mathrm{dL}$ ), thrombocytopaenia $(29000 / \mu \mathrm{L}), \mathrm{C}$ reactive protein $28 \mathrm{mg} / \mathrm{dL}$ and liver dysfunction (aspartate aminotransferase $207 \mathrm{U} / \mathrm{L}$, direct bilirubin $3 \mathrm{mg} / \mathrm{dL}$ and albumin $1.6 \mathrm{~g} / \mathrm{dL}$ ). The newborn VDRL was reactive (1:32) and fluorescent treponemal antibody absorption (FTA-abs) IgM test was positive. Cerebrospinal fluid VDRL was non-reactive and
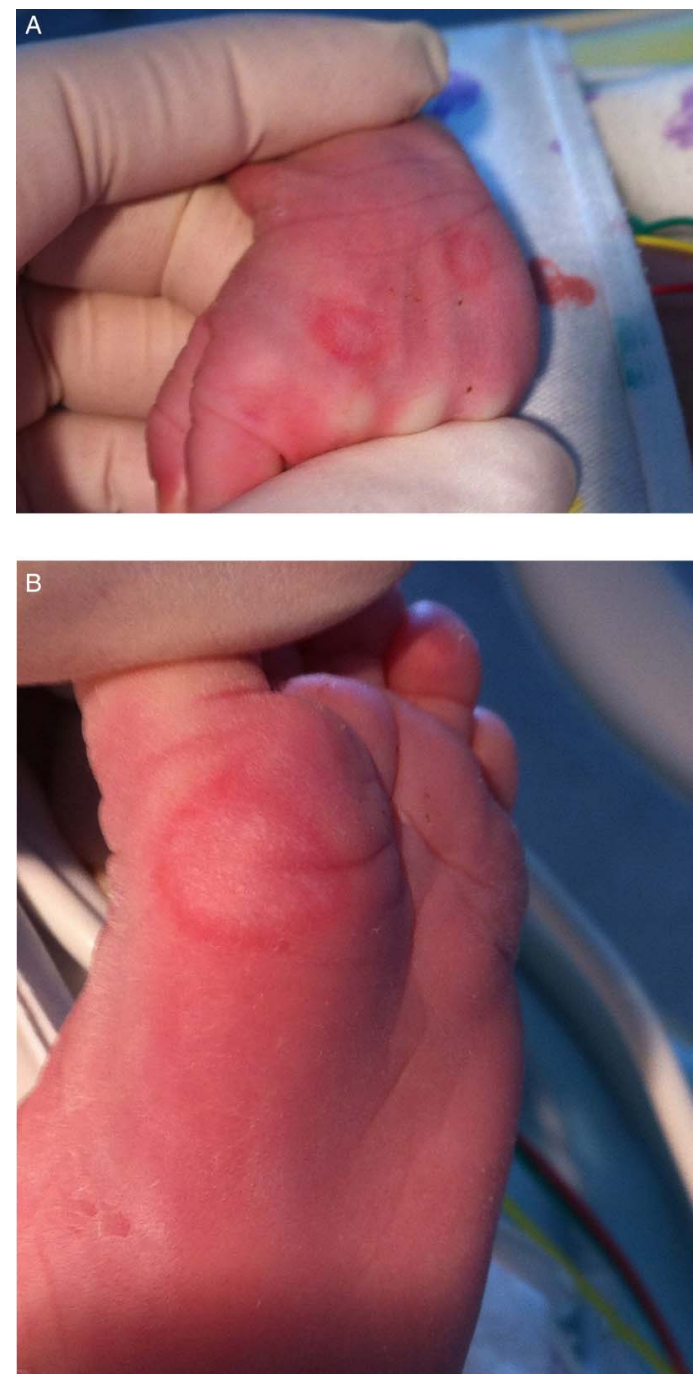

Figure 1 Target macules with erythaematous halo on patient's hands $(A)$ and soles $(B)$.

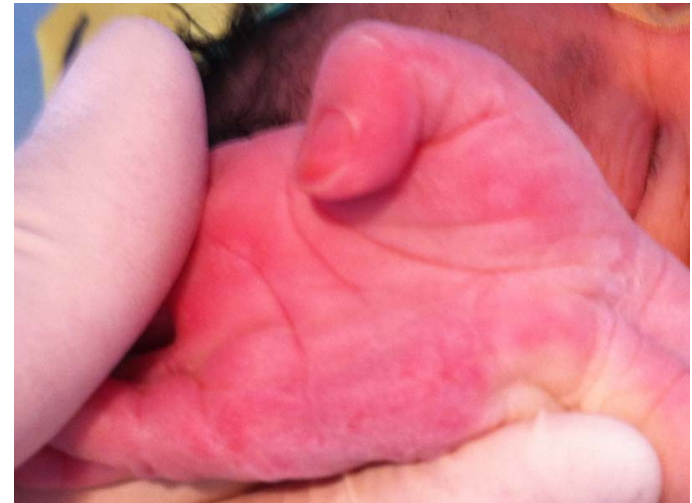

Figure 2 Erythaematous rash prominent on patient's palmar surface of hands.

cerebral ultrasound, hearing test, eye examination and long-bone radiographs were normal. The child was treated with intravenous aqueous crystalline penicillin $\mathrm{G}$ for 14 days, with favourable outcome (reduction in seroreactivity to $1: 16$ after 1 month and seronegativity after 1-year follow-up).

Congenital syphilis (CS) occurs when Treponema pallidum crosses the placenta or during birth by contact with an infectious lesion. Mucocutaneous involvement is present in about $70 \%$ of infants with early CS and it is classically a vesiculobullous or maculopapular rash occurring on the palms and soles. ${ }^{1} 2$ Our patient had a target erythaematous maculopapular rash with typical involvement of the hands and soles. Other signs also include premature delivery, low birth weight, hepatosplenomegaly, pneumonitis, anaemia, thrombocytopaenia and liver dysfunction, as in our case. ${ }^{2}$ Definitive diagnosis of CS can be made based on detection of FTA-abs IgM and a reactive non-treponemal test. ${ }^{3}$ The continuing prevalence of this disease reflects the failure of preventive public health interventions.

\section{Learning points}

- Congenital syphilis remains a worldwide public health problem.

- All pregnant women should be screened for syphilis. Failure to detect or adequately treat maternal disease often results in congenital syphilis.

- Congenital syphilis is a preventable and treatable disease if physicians are aware of its diverse clinical signs. Clinical suspicion and a detailed maternal history provide important clues for the diagnosis of congenital syphilis. 
Competing interests None declared.

\section{Patient consent Obtained.}

Provenance and peer review Not commissioned; externally peer reviewed.

\section{REFERENCES}

1 Woods CR. Syphilis in children: congenital and acquired. Semin Pediatr Infect Dis 2005;16:245-57.
2 Chakraborty R, Luck S. Syphilis is on the increase: the implications for childhealth. Arch Dis Child 2008;93:105-9.

3 European Center for Disease Prevention and Control [Internet] Commission Decision of 28/IV/2008 amending Decision 2002/253/EC laying down case definitions for reporting communicable diseases to the Community network under Decision No 2119/98/EC of the European Parliament and of the Council (cited 9 Febuary 2016). http://ecdc.europa.eu/en/healthtopics/sti/Pages/Case\% 20definition.aspx

Copyright 2016 BMJ Publishing Group. All rights reserved. For permission to reuse any of this content visit http://group.bmj.com/group/rights-licensing/permissions.

BMJ Case Report Fellows may re-use this article for personal use and teaching without any further permission.

Become a Fellow of BMJ Case Reports today and you can:

- Submit as many cases as you like

- Enjoy fast sympathetic peer review and rapid publication of accepted articles

- Access all the published articles

- Re-use any of the published material for personal use and teaching without further permission

For information on Institutional Fellowships contact consortiasales@bmjgroup.com

Visit casereports.bmj.com for more articles like this and to become a Fellow 